\title{
Primary carcinoid tumor of the kidney
}

\section{Böbreğin primer karsinoid tümörü}

\author{
İbrahim Gelincik ${ }^{1} \quad$ Polat Türker $^{2} \quad$ Ömer Özçağlayan ${ }^{3} \quad$ Ramazan Uygur $^{4}$ \\ ${ }^{1}$ Namık Kemal University Faculty of Medicine, Department of Pathology, Tekirdağ, Turkey \\ ${ }^{2}$ Namık Kemal University Faculty of Medicine, Department of Urology, Tekirdağ, Turkey \\ ${ }^{3}$ Namık Kemal University Faculty of Medicine, Department of Radiology, Tekirdağ, Turkey \\ ${ }^{4}$ Namık Kemal University Faculty of Medicine, Department of Anatomy, Tekirdağ, Turkey
}

\begin{abstract}
Primary renal carcinoid tumor is an exceedingly rare neoplasm which was first reported by Rensick et al. in 1966. In a recent comprehensive review of the literature, Murali et al. and Romero et al. reviewed the literature up to 2006 and found 51 and 56 cases, respectively, reported in the literature. The pathogenesis of this tumor is uncertain because neuroendocrine cells are not found in normal adult renal parenchyma. The clinical presentation is similar to other renal tumors thus posing diagnostic dilemmas for clinicians. We report a case of primary carcinoid tumor of the right kidney in a 55-year-old male patient.
\end{abstract}

Keywords: Carcinoid tumor, renal tumours, neuroendocrine, immunohistochemistry.

Öz

Böbreğin primer karsinoid tümörü, ilk olarak 1966 yılında Rensick ve arkadaşları tarafından bildirilen çok nadir bir neoplazmdır. Literatürü kapsamı şekilde 2006 yııına kadar gözden geçiren Murali ve arkadaşları 51 vakanın, Romero ve arkadaşları ise 56 vakanın bildirildiğini bulmuşlardır. Nöroendokrin hücreler normal erişkinlerin böbrek parankiminde bulunmadığından dolayı bu tümörün patojenezi tam olarak açıklanamamıştır. Klinik açıdan diğer böbrek tümörlerine benzediğinden dolayı teşhis güçlügü vardır. Biz 55 yaşındaki erkek hastanın sağ böbreğindeki primer karsinoid tümörü rapor ettik.

Anahtar Sözcükler: Karsinoid tümör, renal tümörler, nöroendokrin, immunohistokimya.

\section{Introduction}

Carcinoid tumors are low-grade malignant neoplasms that arise from neuroendocrine cells with malignant potential that depends on their site of origin (1). These tumors are neuroendocrine tumors mostly found in the gastrointestinal tract $(73.7 \%)$ and respiratory tract (25.1\%) (2). Other localizations like ovary, testis, cervix, biliary duct, breast or gallbladder are rare (3). On gross examination, renal carcinoids present as single, well demarcated, solid, yellow or grey colored tumors. When a carcinoid tumor of the kidney is suspected, great care must be taken to rule out the more common occurrence of metastases from an extrarenal primary site. These tumors usually spread locally, metastases are rare but their frequency increases with the increasing tumor size.

Corresponding Author: Ibrahim GELINCIK

Namık Kemal University Faculty of Medicine, Department of Pathology, Tekirdağ, Turkey

Received: 20.06.2014

Accepted: 14.08.2014
The most common metastases are lymph nodes and liver. We report a man who had a primary carcinoid tumor of the kidney without any evidence of metastasis or carcinoid syndrome.

\section{Case Report}

A 55-year-old man presented with weakness and fever as well as right flank pain. Physical examination was unremarkable except for mild right flank tenderness. Abdominal computed tomography (CT) scan showed normal sized kidney with a hypodense round $92 \times 77 \times 64$ $\mathrm{mm}$ mass in the middle and lower pole of the right kidney. There was no definite hydronephrosis or caliectasis. The patient had no other abnormal findings, such as suspected distant metastasis or lymph node metastasis. Radical nephrectomy was performed with the diagnosis of renal cell carcinoma (RCC). Pathologic study of the nephrectomy specimen showed a welldefined, tan-colored, round and well encapsulated mass in the mid pole of the kidney measuring $7.5 \times 7 \times 6 \mathrm{~cm}$ (Figure-1a). 

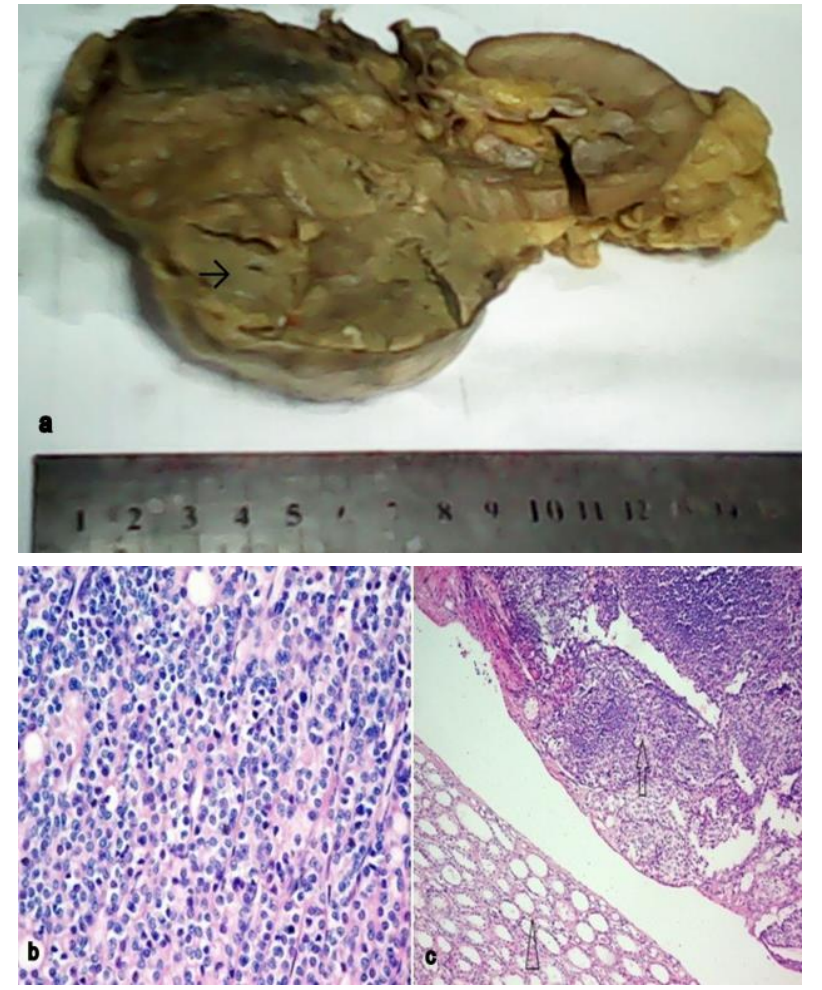

Figure-1. a. Gross specimen is a whitish, soft yellowish solid mass with well-encapsulated margins and bulging contour (arrow). Microscopic appearance. b. Carcinoid cells with tightly packed trabecular pattern of growth typical of carcinoid tumor are polygonal with eosinophilic cytoplasm, round, rather monomorphic nuclei with a granular ("salt and pepper") chromatin pattern (x200). c. Showing tumor cells in the upper right side (arrow) and renal tubules in the lower left side (arrow head) (x40).

Microscopically, the tumor showed tightly packed trabecular growth pattern. Tumor cells showed moderate polymorphism, narrow rim of eosinophilic cytoplasm surrounded round nuclei with granular ("salt and pepper") chromatin (Figure-b, c).

The mitotic index was 1/50 HPF. No necrosis, mitosis, calcifications or atypical cells were detected. Immunohistochemical stains showed positive chromogranin, synaptophysin, NSE and CD56. $1 \%$ of tumor cells were positive for Ki-67, whereas CK7, CK20, CD10, and RCC markers were negative. A diagnosis of typical carcinoid tumor was made with these findings.

\section{Discussion}

The first reported case is by Resnick et al. (4) in 1966. In a recent comprehensive review of the world's literature, Murali et al. (5) and Romero et al. (3) reviewed the literature up to 2006 and found 51 and 56 cases, respectively, reported in the literature. Korkmaz et al. (6) reviewed the literature published after these reports and found 26 more cases reported. The largest report is from several centers of US which had informed 21 cases of renal carcinoid during 36 years (7). Their pathogenesis of this disease is uncertain because neuroendocrine cells are not found in normal renal parenchyma, pelvis and ureter (8), and pre-existing hyperplasia of neuroendocrine cells found within the foci of metaplastic or teratomatous epithelium is the most likely pathogenesis of the disease.

Several radiographic findings are common in carcinoid tumors, including no or minimal enhancement, heterogeneity, and calcifications which were present in $75 \%, 60 \%$, and $26 \%$ of reported lesions, respectively (3). There is, however, no specific finding on CT or magnetic resonance imaging (MRI) that can by itself differentiate renal carcinoid tumors from other types of renal tumors before surgery. Typically, carcinoid tumors present with a well-circumscribed, non-enhancing or slightly enhancing mass on CT with a solid component (3) but are occasionally associated with cystic components.

Carcinoid tumors are characteristically low-grade malignant tumors with neuroendocrine differentiation. They are located mainly in the gastrointestinal (74\%) and respiratory (25\%) tracts (2). In $<1 \%$ of cases, carcinoid tumors are reported in the genitourinary system. A classification system established in 2000 and updated in 2010, differentiates between neuroendocrine tumors (NETs) and neuroendocrine carcinomas (9). The proliferation index (Ki-67) is important in this classification. Thus, tumors are divided into welldifferentiated NETs ( $<2 \mathrm{~cm}$ in size, $<2 \% \mathrm{Ki}-67$ index), well-differentiated neuroendocrine carcinomas $(>2 \mathrm{~cm}$ in size, $>2 \% \mathrm{Ki}-67$ index, or angioinvasive), and poorly differentiated neuroendocrine carcinomas (>20\% Ki-67 index). The tumor of our case had minimal mitotic activity (1/50 high-power field) without vascular, lymphatic, and perineural invasion or necrosis.

Grossly, carcinoid tumors are usually single, yellowish to tan to grey tumors. The reported sizes range from 2 to $17 \mathrm{~cm}$ (average $6.4 \mathrm{~cm}$ ). The lesion is usually solid but occasionally may be associated with a cystic component. The lesion in our case was solid and in $7.5 \times 7 \times 6 \mathrm{~cm}$ sizes. Although renal carcinoid is usually well demarcated, in several cases, extrarenal spread with fat tissue infiltration may be seen and $10 \%$ show vascular invasion. Histologically, the growth pattern is the same as in other locations: trabecular or ribbon-like arrangement or solid nests with peripheral palisading. Stroma is highly vascularized. Cells are rather monomorphic with granular eosinophilic cytoplasm and blurred cytoplasmic borders.

Nuclei are round to oval, characteristically uniform in size and shape, with coarse chromatin. The nucleoli are small. Single mitotic figures may be seen. Calcification, hemorrhage or necrosis are uncommon. The diagnosis is confirmed by immunohistochemistry with positive reactions for common neuroendocrine markers such as 
chromogranin, enolase or synaptophysin (3). In our case, tumor cells were positive for synaptophysin, chromogranin, NSE and CD56.

Renal carcinoid tumors are indistinguishable from other renal tumors such as RCC pre-operatively like in our case, and histopathology only results in the final diagnosis (4). The relatively large size of the tumors at the time of diagnosis is reported to correlate well with the incidence of metastasis. Outcome is not related to the presence of metastasis at the time of diagnosis because some of the patients survived for a long time despite of the presence of metastatic disease. There was not metastasis in our case. Complete surgical resection is the primary treatment of renal carcinoid and curative for localized disease (10). Partial nephrectomy is a good alternative regarding the location and diameter of the tumor. Lymph node dissection associated with radical/partial nephrectomy allows for optimal staging of the disease. However, no trial so far has shown its direct impact on survival like any neo/adjuvant treatment (chemotherapy, octreotide, targeted therapy or radiotherapy). Conventional methods of imaging are inadequate for detecting smaller carcinoids, so somatostatin receptor scintigraphy should complement CT and MRI when searching for occult or metastatic disease. Close follow-up after surgery is necessary. In conclusion, renal carcinoids have better prognosis compared to other renal neoplasms and nephrectomy is curative in localized disease and recommended even in metastatic disease.

\section{References}

1. Kulke MH, Mayer RJ. Carcinoid tumors. N Engl J Med 1999;340(11):858-68

2. Modlin IM, Sandor A. An analysis of 8305 cases of carcinoid tumors. Cancer 1997;79(4):813-29.

3. Romero FR, Rais-Bahrami S, Permpongkosol S, Fine SW, Kohanim S, Jarrett TW. Primary carcinoid tumors of the kidney. J Urol 2006;176(6 Pt 1):2359-66.

4. Chung HY, Lau WH, Chu SM, Collins RJ, Tam PC. Carcinoid tumor of the kidney in a Chinese woman presenting with loin pain. Hong Kong Med J 2007;13(5):406-8.

5. Murali R, Kneale K, Lalak N, Delprado W. Carcinoid tumors of the urinary tract and prostate. Archives of Pathology and Laboratory Medicine 2006;130(11):1693-706.

6. Korkmaz T, Seber S, Yavuzer D, Gumus M, Turhal NS. Primary renal carcinoid: Treatment and prognosis. Crit Rev Oncol Hematol 2013;87(3):256-64.

7. Hansel DE, Epstein JI, Berbescu E, Fine SW, Young RH, Cheville JC. Renal carcinoid tumor: A clinicopathologic study of 21 cases. Am J Surg Pathol 2007;31(10):1539-44.

8. Shurtleff BT, Shvarts O, Rajfer J. Carcinoid tumor of the kidney: Case report and review of literature. Rev Urol 2005;7(4):22933.

9. Lüttges J. What's new? The 2010 WHO classification for tumours of the pancreas. Pathologe 2011;32(2):332-6.

10. Lane BR, Chery F, Jour G: renal neuroendocrine tumors: A clinicopathological study. BJU Int 2007;100(5):1030-35. 